\title{
Behavior of iodine in the soil-plant system
}

\author{
Y. Muramatsu, S. Yoshida, T. Ban-nai and S. Amachi ${ }^{1}$ \\ National Institute of Radiological Sciences, Anagawa 4-9-1, Inage-ku, Chiba 263-8555, Japan \\ ${ }^{1}$ Chiba University: Matsudo 648, Matsudo-shi, Chiba 271-8510, Japan
}

\begin{abstract}
Ahstract. In order to understand the behaviour of radioactive and stable iodine in the environment, we have carried out radiotracer experiments and chemical analyses in the soil-plant systems. Parameters important for the assessment of radioiodine movernent from the enviromment to man, e.g. soil-plant transfer factors for various agricultural crops and soil-solution distribulion coefficient for different soils, were obtained. Mechanisms of iodine sorption and desorption on soil were also studied. Microorganisms and/or their products (e.g. enzymes) were found to play an important role in the fixation of iodine on soil. Iodime was observed to be desorbed from the flooted soils due to the reducing conditions (low Eh) created by the microbial activities. From the soil-rice plant system biogenesis methyl iodide was found to be evaporated into the atmosphere. Through experiment using ${ }^{125}$ l tracer, we found that volatile organic jodine was produced due to microbial activities (including bacterial activities).
\end{abstract}

\section{INTRODUCTION}

Radioiodine is one of the most important radionuclides released from nuclear industries into the environment, while from a nutritional viewpoint, stable iodine is an important nutrient element. When iodine is ingested into the human body it is concentrated in the thyroid gland. Therefore, it is necessary to obtain information on the behavior of radioiodine in the environment for safety assessment. Two radioisotopes of iodine, ${ }^{129} \mathrm{I}$ (half-life: $1.6 \times 10^{7} \mathrm{y}$ ) and ${ }^{131} \mathrm{I}$ (half-life: $8 \mathrm{~d}$ ), are specifically imponant in terms of radioecology. Since the amount of ${ }^{131}$ I produced in a reactor is much higher than that of ${ }^{129} \mathbf{I}$, the former isotope is more important at the time of a reactor accident. However, ${ }^{131_{I} \text { decays away }}$ within several months of contamination. The long radiological half-life of ${ }^{129} \mathrm{I}$, on the other hand, prevents this nuclide from disappearing, causing it to enter the geochemical and ecological cycles of stable iodine. Interest in ${ }^{129} \mathrm{I}$ is increasing, particularly regarding the operation of nuclear fuel reprocessing plants. Therefore, it is important to study biogeochemical cycling of both stable and radioactive iodine in the environment for a reliable assessment [1-2].

In this paper, we summarize our recent investigations [e.g. 3-10] on (1) transfer of iodine from soil to plants; (2) sorption and desorption phenomena of iodine in soil; (3) volatilization of iodine from the soil-plant system; and (4) production of methyl iodide by bacterial activities. Some new data are also included.

\section{MATERIALS AND METHODS}

\subsection{Transfer of iodine from soil to plants}

Soil samples (Andosol; one of the most important soil types in Japan) were mixed with radioiodine tracer, ${ }^{125} \mathrm{I}$ (half-life: $59.4 \mathrm{~d}$, as an analog of ${ }^{129} \mathrm{I}$ ). Young seedlings (or seeds) were planted in the pots (3 litre) with spiked soil. They were cultivated in a plant growth chamber [3,4]. Maximum light intensity of the chamber was about 70000 lux. During cultivation, temperature and moisture in the chamber were controlled in accordance with the outdoor conditions. After the plants were harvested, they were 
separated into organ parts (e.g. leaves, grains) and $125_{\text {I concentrations were determined with an } \mathrm{NaI}}$ scintillation counter. The soil-plant transfer factor (or concentration ratio) is defined as "the $125_{I}$ concentration in the plant part $\left(\mathrm{Bq} \mathrm{g}^{-1}\right.$, fresh)" divided by "the ${ }^{125}$ I concentration in soil $\left(\mathrm{Bq} \mathrm{g}^{-1}\right.$, dry)."

\subsection{Sorption and desorption phenomena of iodine in soil}

Sorption of iodide $\left(\mathrm{I}^{-}\right)$and iodate $\left(\mathrm{IO}_{3}{ }^{-}\right)$on soils was examined by the batch method [3]. Samples $(3 \mathrm{~g})$ were mixed with deionized water $(30 \mathrm{ml})$ in polyethylene bottles $(50 \mathrm{ml})$, and radioiodine tracers ( ${ }^{125} \mathrm{I}^{-}$and ${ }^{125} \mathrm{IO}_{3}{ }^{-}$) were added. After shaking, the samples were centrifuged and aliquots of the supematant solution were counted with an Nal counter. The soil-solution distribution coefficient $\left(K_{d}\right)$ was calculated from the activities remaining in the solution. For the desorption experiment, soil solutions from the pots were collected with a porous cup during the experiment and the concentrations of ${ }^{125} I$ were determined. Soil Eh was also measured. Details of the experiment and the measurements have been described in our previous papers [5 - 7].

\subsection{Volatilization of iodine from the soil-plant system}

Radioiodine volatilized from plants was collected with two traps. The first trap contained silver wool for collecting inorganic iodine and the second trap contained activated charcoal (supplemented with triethylendiamine) for collecting organic jodine [8]. Activities were measured with an NaI scintillation counter. Gas chromatographic mass spectrometry (GC-MS) and gas chromatography with an electron capture detector (ECD-GC) were also used to identify the iodine species [8].

\subsection{Production of methyl iodide by bacterial activities}

Soil solution (surface water) was collected from a rice paddy field in Ibaraki Prefecture. Bacterial cell suspension was prepared from Mesorhizobium sp. MRCD19 which was isolated from agricultural soil in Ibaraki Prefecture. The bacterium was grown in an artificial medium, washed and resuspended in $20 \mathrm{mM}$ potassium phosphate buffer ( $\mathrm{pH} 7.0$ ). Final concentration of the cell suspension was about $10^{9}$ cells $\mathrm{ml}^{-1}$. Volatile radioiodine was introduced into the two traps (silver wool for inorganic iodine and charcoal for organic iodine) by sweeping nitrogen gas. Details of the method were described in our paper [10].

\section{RESULTS AND DISCUSSION}

\subsection{Transfer of iodine from soil to plants}

The soil-to-plant transfer factors (or concentration ratio of radionuclide between plants and soil) in the edible parts of crops obtained are shown in Table 1. A wide variation of the values was observed, i.e. $0.0002-4.0$. The value for the common Japanese leaf vegetable komatsuna was comparable to the IAEA (1982) [11] recommended value (0.02) for edible parts of common crops, which include se veral different crops. However, the values for sweet potato, Yam, tomato, carrot, soybeans and rice were significantly lower than their leaf values. This indicates that translocation of iodine with photosynthate from leaves into fruits and grains is very small. The transfer factor for polished rice $(0.002)$ was less than $1 / 1000$ of that of the rice plant leaves (4.0). The value for brown rice (unpolished rice) was 3 times higher than that for polished rice, i.e. nearly $70 \%$ of the radioiodine was removed with the bran by polishing. Since the transfer factor of iodine for agricultural crops varies widely, we note that only one representative value for the transfer factor is insufficient. Different values of transfer factors should be established for $p$ lant groups as categorized by the type of their edible part. In addition to the type of crops, the transfer factors are also expected to be influenced by the sorption characteristics of soils. High $\mathrm{K}_{\mathrm{d}}$ values in common 
Japanese field soil (see next section) may explain the relatively low transfer factors observed in our experiments using Andosol.

\subsection{Sorption and desorption phenomena of jodine in soil}

The soil-solution distribution coefficient $\left(K_{d}\right)$ is the most important parameter for assessing the migration of radionuclides in soil. The resuits obtained for soils and minerals are shown in Table 2. High $K_{d}$ values (high sorption) were found in soils having high concentrations of total organic carbon, active-Al and active-Fe ( $\mathrm{Al}$ and $\mathrm{Fe}$ extracted by a mixture of oxalic acid and ammonium oxalate) [12]. Andosol, one of the most typical Japanese soils derived from deposits of volcanic ash, showed specifically high $K_{d}$ values. These results indicated that added radioiodine was associated on the surface of sesquioxides of $\mathrm{Fe}$ and $\mathrm{Al}$, noncrystalline silicates such as allophene, organic materials and complexes of metals with humus. Stable iodine concentrations in Andosol are known to be higher than other soils $[9,14]$. This should be related to the high sorption capacity of Andosol for iodine.

Table 2 Distribution coefficient $\left(\mathrm{K}_{\mathrm{d}}, \mathrm{ml}^{\cdot 1}\right)$ for soil and related materials.

\begin{tabular}{|c|c|c|}
\hline & $\mathrm{I}$ & $\mathrm{IO}_{3}{ }^{-}$ \\
\hline Andosol (wheat field) & 7500 & 7000 \\
Gray lowkand soil (paddy field) & 560 & 430 \\
Sandy soil & 35 & 32 \\
$\mathrm{Kaolinite}$ & 0.5 & 0.7 \\
$\mathrm{Al}_{2} \mathrm{O}_{3}$ & 0.2 & $<0.1$ \\
$\mathrm{Fe}_{2} \mathrm{O}_{3}$ & 47 & 520 \\
\hline
\end{tabular}

It was found that the iodide sorption was drasticaliy decreases in autoclaved soils. The following three possibilities can be expected to explain the decrease of iodine sorption on soil by autoclaving (or heating); (a) living microorganisms which acted in the iodine fixation were killed, (b) products of microorganisms (e.g. enzymes) which affect the iodine fixation were decomposed and (c) soil fractions which related to the iodine sorption were destroyed. We expect that the effect (b) should be the most important factor controlling the iodide sorption. In contrast to the iodide sorption, the decrease of the iodate sorption by autoclaving was markedly smaller. This indicated that the sorption sites for iodate were not so sensitive to heating and the sorption mechanisms differed between the two species.

Desorption of iodine from the flooded soil during the cultivation of rice plants in pots was studied by radiotracer experiments using $125_{\mathrm{I}}$. The changes of the redox potential (Eh) in soil and $125_{\text {I activities }}$ in soil solution collected with porous-cups were measured as a function of time [7]. The results obtained are shown in Fig. 1. In the first 6 weeks after planting, the activity of $125_{I}$ in the solution of the cultivated pots was very low. This was explained by the high $\mathrm{Kd}$ value (more than 1000 ) for the soil used in the experiments. However, the activity in the solution collected from the cultivated soils 
markedly increased from about 40 days after the planting. It was suggested that the increase was caused by the effects of roots and/or microorganisms in the soil. Eh decreased considerably after soil was waterlogged. The decrease of Eh was larger in the pots with rice plants in comparison to the uncultivated pot. When soil is flooded with water, molecular oxygen disappears and nitrates diminish due to the activities of aerobes and facultative anaerobes, consequently Eh drops. With the drop of Eh, a succession of microorganisms occurs, and sulfides and a little later, methane, are formed by strict anaerobes [12]. In our experiment, we observed that the Eh value dropped to about $-240 \mathrm{mV}$ in the pots with plants. At the end of the cultivation experiment $\mathrm{Eh}$ value of one of the cultivated pots increased. The decrease of Eh in the pot without plants (uncultivated soil) was smaller (down to about $0 \mathrm{mV}$ ) which
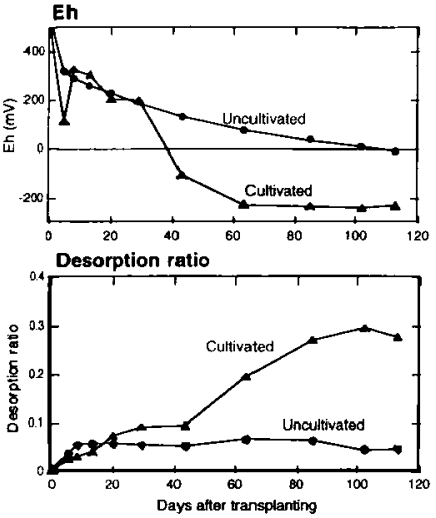

Fig. I Temporal changes of Eh and desorption ratio of iodine in Gray lowland soil after flooding resulted in the low iodine desorption. High desorption was frequently observed when the Eh dropped to about $-100 \mathrm{mV}$ or below. From these results we could conclude that the desorption of iodine from soil was also controlled by the effects of microorganisms. Due to the reducing conditions (low Eh) created by the microorganisms in the flooded soils, iodine once adsorbed on the soils was leached into the soil solution; consequently total iodine concentration in paddy soil was considerably lower than forest and upland field soils with time.

\subsection{Volatilization of iodine from the soil-plant system}

During the cultivation of rice plants, radioiodine added to the soil was found to be evaporated from the soil-plant system as methyl iodide (see Fig. 2). The iodine emission was highly stimulated by the presence of plants. The emission of gaseous iodine from rice plants grown on flooded soil was much higher than that of plants grown on unflooded soil, such as oat plants. Seasonal patterns in the iodine emission were observed for rice and oat plants. The emission rate increased with time from planting and the maximum value was observed in the late tillering stages (shortly before heading) of the plants. The chemical species of volatilized iodine was identified as methyl iodide $\left(\mathrm{CH}_{3} \mathrm{~L}\right)$ from gas chromatography [8].

The following mechanism for the high production of methyl iodide in the soil-rice plant system seems reasonable. Microorganism activities in the soil (particularly the rhizosphere) are increased by flooding and the effects of root exudates and/or root autolysis, so that eventually an anaerobic condition (low Eh) is generated. Under this condition iodine is dissolved from the soil into the soil solution as iodide $\left(\mathrm{I}^{-}\right)$. We presume that the iodide dissolved in the soil solution in the rhizosphere is biomethylated, possibly by the effect of enzymes produced by microorganisms or roots. For example, the enzyme methyl halide transferase might be a candidate for methylating iodide. The biogenic methyl iodide produced in the soil might be transported through the intercellular gas space and aerenchym system in 
the plants into the atmosphere, presumably by a mechanism similar to methane emission from rice fields. The volatilization phenomena should also be important in understanding the biogeochemical cycle of iodine (and possibly also of bromine) in the environment.

Iodine-129 was still detected in the air collected around a reprocessing plant several years after its closing as reported by Brauer and Strebin [1]. This might be explained by the volatilization of the nuclide from the contaminated soil-plant system. Volatilization of iodine from the soil-plant system is also thought to be important to understanding the behavior of the long-lived ${ }^{129} \mathrm{I}$ in the environment and this pathway should be considered in establishing a transfer model for ${ }^{129} \mathrm{I}$ in the environment.

\subsection{Production of methyl iodide by bacterial activities}

We have developed a reliable method using ${ }^{123}$ I tracer for direct determination of volatile iodine produced in aqueous environmental samples [10]. Using this method, we studied volatile organic and inorganic iodine species produced during incubation of soil solution and bacterial cell suspension. Results for two materials are summarized in Table 3. Volatile iodine production was observed, although the extent of the production was very low. Iodine volatilized mainly as organic iodine from the samples.

Table 3 . Volatile iodine production in aqueous environmental samples.

\begin{tabular}{llcccc}
\hline \multirow{2}{*}{ Sample } & & & \multicolumn{3}{c}{ Filtered/Autoclaved } \\
\hline $\begin{array}{l}\text { Soil } \\
\text { solution }\end{array}$ & Emission rate $\left(10^{-3} \%\right)^{*}$ & 8.0 & 0.22 & 0.93 & 0.68 \\
& Relative production & 100 & 2.8 & 12 & 8.5 \\
\hline $\begin{array}{l}\text { Bacterial cell } \\
\text { suspension }\end{array}$ & Emission rate $\left(10^{-3} \%\right)$ & 65 & 0.0036 & 0.023 & 0 \\
& Relative production & 100 & 0.0055 & 0.035 & 0 \\
\hline
\end{tabular}

- Percentage $\left(10^{-1} \%\right)$ of radioactivity collected in the traps of activated charcoal or silver wool compared with the total activity added to the samples.

* Organic iodine production in each sample was expressed as 100.

It is interesting to note that the organic iodine production decreased markedly when the samples were filtered or autoclaved. These results support the idea that organic iodine species such as methyl iodide are produced biologically in natural environments. In relation to the soil-rice plants system as mentioned above, contribution by bacteria should be very important to understand the production of 
methyl iodide in the soil environment. Results obtained in additional experiments indicate that aerobic bacteria are more important in the methyl iodide production than anaerobs.

The main contributor to organic iodine production in natural environments is still controversial. Fungi, algae and plants are known to produce methyl iodide, although the amounts of the production are not known. In this study, however, it was observed that volatile organic iodine is produced biologically in soil solution, and that a general soil bacterium, Mesorhizobium sp., is capable of producing volatile organic iodine (i.e. $\mathrm{CH}_{3} \mathrm{I}$ ) from iodide. These findings clearly suggest that microorganisms, including bacteria, are important in producing organic iodine in natural environments. We are now conducting studies on the bacterial organic iodine production both in terrestrial and marine environments.

\section{References}

[1] Brauer F. P. and Strebin R.S. Jr., In Environmental Migration of Long-lived Radionuclides (LAEA-SM-257), IAEA, Vienna, (1982) 465-480.

[2] Muramatsu Y. and Yoshida S.. J. Radioanal Nuclear Chemistry, Articles, 197 (1995) 149-159.

[3] Muramatsu Y., Uchida S., Sumiya M., Otmomo Y. and Obata H., Water, Air and Soil Pollution, 45 (1989) 157-171

[4] Muramatsu Y., Yoshida S. and Ban-nai T., J. Radioanal. Nuclear Chemistry, Articles, 194 (1995) 303-310.

[5] Muramatsu Y., Uchida S., Sriyotha P. and Sriyotha K., Water, Air and Soil Pollurion, 49 (1990) 125-138 .

[6] Yoshida S., Muramatsu Y. and Uchida S., Water, Air and Soil Pollution, 63 (1992) 321 -329.

[7] Muramatsu Y., Yoshida S., Uchida S. and Hasebe A., Water, Air and Soil Pollution, 86 (1996) 359-371.

[8] Muramatsu Y. and Yoshida S., Atmospheric Environment, 29 (1995) 21-25.

[9] Muramatsu Y. and Yoshida S., Geomicrobiology J. 16 (1999) 85-93.

[10] Amachi S., Muramatsu Y, Kamagata T., J. Radiounah Nuclear Chemistry. 246 (2000) 337-342.

[11] IAEA, LAEA Safety Series No. 57, IAEA. Vienna (1982).

[12] Whitehead D.C., Environmental International, 10 (1984) 321-339.

[13] Takai Y., J. Korean Soc. Soil Sci. Fert. 17 (1984) 187-199.

[14] Yuita K., Nobusawa Y., Shibuya M. and Aso S., Soil Sci. Plant Nutr., 28 (1982) 315 15-336. 